\title{
Potensi Model Inkuiri Terbimbing Dipadu Edutainment terhadap Penguasaan Konsep Siswa SMP
}

\author{
Shoimatun Febriyani ${ }^{1}$, Hadi Suwono ${ }^{1}$, Ibrohim ${ }^{1}$ \\ ${ }^{1}$ Pendidikan Biologi-Universitas Negeri Malang
}

\begin{tabular}{l}
\hline \hline INFO ARTIKEL \\
\hline Riwayat Artikel: \\
Diterima: 07-05-2019 \\
Disetujui: 11-12-2019 \\
\hline
\end{tabular}

\section{Kata kunci:}

guided inquiry; edutainment;

mastery of concepts; inkuiri terbimbing;

edutainment;

penguasaan konsep

\section{ABSTRAK}

Abstract: This study aims to investigate the potencial of guided inquiry models edutainment combined toward the mastery concepts. The design of this research use quasi experiment. The population of this studdy was all the second grades students of SMP N 18 Malang while the sampling of the study was 8G, 8H dan 8E. The used instrument was 20 multiple choice to measure the mastery concepst of students. The result of the study was guided inquiry models edutainment combined potencially can improve mastery of concepts students.

\begin{abstract}
Abstrak: Penelitian ini bertujuan untuk mengetahui potensi model inkuiri terbimbing dipadu edutainment terhadap penguasaan konsep. Rancangan penelitian ini menggunakan eksperimental semu (Quasi Experiment). Populasi dalam penelitian ini adalah siswa kelas VIII SMP 18 Malang sedangkan sampel penelitian yaitu kelas 8G, $8 \mathrm{H}$ dan $8 \mathrm{E}$. Instrumen yang digunakan berupa berupa 20 butir soal pilihan ganda pada masing-masing materi yang dibelajarkan. Hasil penelitian ini adalah model inkuiri terbimbing dipadu edutainment berpotensi dalam meningkatkan penguasaan konsep siswa.
\end{abstract}

\author{
Alamat Korespondensi: \\ Shoimatun Ferbriyani \\ Pendidikan Biologi \\ Universitas Nergeri Malang \\ Jalan Semarang 5 Malang \\ E-mail: shoimatunfebriyani@gmail.com
}

Ilmu Pengetahuan Alam dalam penerapannya merupakan pengetahuan yang harus berdasarkan observasi dan eksperimen (Hohenberg, 2010). Pembelajaran IPA diperlukan untuk mengembangkan kemampuan siswa dalam hal keterampilan dan pemahaman yakni konseptual serta prosedural (Treffinger, Young, Selby, \& Shepardson, 2002). Proses belajar IPA dapat meningkatkan kemampuan psikomotorik, afektif, dan kognitif siswa dengan mengembangkan penguasaan konsep siswa (Ali, 2013). Konsep adalah kemampuan siswa mengelompokkan beberapa ilmu dan pengalaman dalam kelompok-kelompok tertentu sehingga lebih mudah untuk mengonstruk beberapa materi yang dipelajari (Arends, 2013). Menurut Purwanto (2008) penguasaan konsep bukan mengingat konsep yang telah dipelajari, namun mengungkapkan kembali dengan bahasa sendiri sehingga mudah dipahami. Pembelajaran IPA menyajikan kegiatan investigasi dan eksperimen sehingga dapat meningkatkan keterampilan, pengetahuan dan sikap untuk membangun konsep-konsep IPA (Zeidan \& Jayosi, 2015)

Berdasarkan penilaian akhir tahun 2018 di SMP Malang diperoleh data bahwa nilai rata-rata kelas mata pelajaran IPA yakni 38,148. Hal tersebut menunjukkan bahwa hasil belajar kognitif atau penguasaan konsep IPA masih sangat kurang. Adapun hasil wawancara dan observasi dengan salah satu guru IPA diperoleh data bahwa pembelajaran IPA kelas delapan yang sering dilakukan adalah presentasi kelompok sehingga kegiatan praktikum atau eksperimen masih jarang dilakukan. Siswa merasa bosan dengan kegiatan yang dilakukan. Guru menyadari perlu adanya model pembelajaran menarik yang dapat memberikan kesan nyaman serta meningkatkan penguasaan konsep siswa.

Masalah tersebut dapat diatasi dengan inovasi pembelajaran yang mengaktualisasi kemampuan dan aktivitas siswa (Hariyadi, Ibrohim, \& Rahayu, 2016). Pembelajaran yang dapat meningkatkan keaktifan dan pemahaman terhadap IPA adalah inkuiri (Llewellyn, 2013). Hal ini sebagaimana dijelaskan oleh Anggareni et al. (2013) pembelajaran inkuiri yakni pembelajaran yang melibatkan siswa secara intelektual dan fisik untuk menyelesaikan masalah yang diberikan. Pembelajaran Inkuiri memberikan pengalaman-pengalaman belajar siswa. Proses pembelajaran inkuiri yang berlangsung berpusat pada siswa. Siswa diberi kesempatan untuk aktif dalam belajar baik mental, intelektual, dan sosial emosional. Pembelajaran inkuiri selain berorientasi pada hasil juga berorientasi pada proses belajar. Tujuannya adalah untuk mengembangkan kemampuan berpikir (Fatwa et al., 2018).

Model pembelajaran inkuiri adalah sebuah model yang didasarkan teori konstruktivisme (Ural, 2016). Konstruktivisme adalah sebuah sudut pandang pembelajaran yang mempertimbangkan keharusan siswa aktif membangun pengetahuan sendiri karena pemahaman teori dan pengetahuan. Guru tidak mengambil peran sebagai seorang yang mentransfer pengetahuan, tetapi sebagai fasilitator (Ural, 2016; Syarkowi et al., 2018) dalam belajar yang membantu siswa untuk membangun pengetahuan. 
Keterlibatan siswa dalam pembelajaran dapat memudahkan penyimpanan informasi jangka panjang selanjutnya akan berdampak pada pemahaman konsep (Syarkowi et al., 2018). Konsep dikonstruksikan oleh siswa melalui serangkaian inkuiri (Darwis, 2015). Berdasarkan hasil penelitian Annisa \& Rohaeti (2018) ada perbedaan signifikan penguasaan konsep siswa yang diajar dengan inkuiri lebih baik daripada penggunaan 5M. Inkuiri terbimbing secara keseluruhan menunjukkan penguasaan konsep lebih baik dibandingkan dengan siswa yang mendapatkan pembelajaran dengan model konvensional (Ogan-bekiro \& Arslan, 2014; Sholikhan, 2017; Hutahaean \& Harahap, 2017). Penemuan konsep melalui kegiatan investigasi atau eksperimen dapat memberikan pengalaman belajar yang bermakna. Kebermaknaan dalam belajar akan berdampak pada daya ingat dan pemahaman siswa terhadap konsep-konsep IPA sehingga hasil belajar menjadi meningkat ( Fatwa, et al., 2018).

Lebih lanjut, Eastwell (2006) pembelajaran inkuiri masih menimbulkan ketakutan siswa dalam belajar karena terlalu serius sepertihalnya seorang ilmuwan. Tidak ada perbedaan yang signifikan dalam peningkatan penguasaan konsep siswa secara dinamis. Model inkuiri dapat meningkatkan keterampilan, namun tidak memudahkan pengetahuan konsep jika siswa sudah mengetahui kontennya (Ogan-bekiro \& Arslan, 2014). Penggunaan model inkuiri terbimbing masih membuat siswa merasa tidak nyaman dalam mengikuti kegiatan pembelajaran (Douglas, 2009). Dengan didorong pernyataan Praptiwi et al. (2012) bahwa inkuiri terbimbing selain memiliki kelebihan dapat meningkatkan keterampilan proses sains, tetapi memiliki kekurangan yaitu kesulitan dalam mengorganisasikan materi dan kurang optimalnya pemahaman siswa, terlalu serius sehingga terkadang siswa tidak merasa nyaman untuk mengikuti proses pembelajaran. Pembelajaran yang perlu dikembangkan yakni pembelajaran yang memberikan kenyamanan diantara siswa sesuai dengan kemampuan yang dimiliki serta memperkaya keaktifan siswa dalam belajar menggunakan variasi dengan model inkuiri terbimbing (Douglas, 2009).

Proses pembelajaran yang nyaman akan membantu siswa dalam mengikuti seluruh kegiatan dan meningkatkan pemahaman siswa (Febriyani, Isnaeni, \& Irsadi, 2016). Selain itu, pembelajaran menyenangkan dapat juga memberikan kenyamanan bagi siswa (Copra \& Chabra, 2013; Pramesthi et al., 2015). Penerapan pembelajaran menyenangkan dan metode inkuiri terbimbing dapat meningkatkan rasa ingin tahu dan prestasi belajar (Pramesthi et al., 2015). Pembelajaran inkuiri yang menyenangkan dapat mengatasi permasalahan sains (keilmuan) yang kurang apabila ada kegiatan yang menghibur (Montuori, 2008). Inovasi pembelajaran inkuiri di kelas dapat dilakukan dengan strategi edutainment. Edutainment merupakan bagian dari pendekatan jelajah alam sekitar yang memiliki karakter menyenangkan(Mulyani et al., 2008).

Edutainment merupakan kegiatan education dan entertaniment (Rusydi., 2017) dengan kata lain adalah belajar sambil bermain. Edutainment merupakan kegiatan pembelajaran yang memiliki unsur pembelajaran ilmu, proses keilmuan, keterampilan berkarya, kerjasama, permainan mendidik, kompetisi, tantangan, dan sportivitas (Marianti, 2006). Menciptakan suasana menyenangkan dapat dilakukan dengan membuat pembelajaran yang lebih rileks (tidak tegang) mengaitkan materi ajar dengan kehidupan nyata, belajar dengan permainan akan memberikan dorongan siswa untuk berpikir dan berpendapat (Sofyan \& Ibrahim, 2017). Edutainment dilakukan dengan permainan-permainan mendidik yang sifatnya memberikan tantangan dan membuat siswa antusias untuk mengikuti proses pembelajaran (Cai et al., 2006; Adieze, 2016).

Edutainment memiliki unsur hiburan yang dapat diaplikasikan dalam permainan yang menantang. Permainan membuat siswa termotivasi untuk mengeksplorasi kemampuannya. Penggunaan permainan dalam pembelajaran dapat menambah pengetahuan dan keterampilan siswa (Cai et al., 2006). Permainan dapat meningkatkan kemampuan kognitif siswa dengan cara memberikan permainan yang memiliki pola pikir analisis (Shih \& Hui-yu, 2014). Permainan juga mampu meningkatkan pemahaman konsep (Pan, 2006). Menurut Pasawano (2015) penerapan pembelajaran edutainment mampu mengubah suasana lebih menghibur dan menarik siswa untuk belajar karena suasana belajar yang menyenangkan akan berdampak dalam pencapaian pengetahuannya dan merespons kegiatan pembelajaran yang sedang dipelajari. Tidak hanya kegiatan permainan yang ditonjolkan melainkan memberikan kesempatan siswa secara nyaman untuk mengaktualisasi diri serta mengonstruk pengetahuan yang dikemas secara menghibur dan menyenangkan (Sorathia \& Servidio, 2012). Tujuan penelitian ini adalah untuk mengetahui potensi model inkuiri terbimbing dipadu edutainment terhadap penguasaan konsep siswa.

\section{METODE}

Rancangan penelitian ini menggunakan eksperimen semu (Quasi Experimental Design). Desain penelitiannya adalah non randomized pretest-postest control group design yang terdiri atas satu kelas eksperimen, satu kelas kontrol positif dan satu kelas kontrol negatif. Populasi yang terlibat pada penelitian ini adalah seluruh siswa kelas VIII SMP Negeri 18 Malang tahun ajaran 2018/2019. Instrumen pengukuran yang digunakan dalam penelitian ini adalah tes penguasaan konsep yang tervalidasi.

Tes penguasaan konsep terdiri dari 20 soal pilihan ganda setiap materi. Rancangan penelitian ini memiliki tiga tahapan yaitu tahap persiapan, tahap pelaksanaan dan tahap pelaporan. Pada tahap persiapan dilakukan penyusunan instrumen penelitian, melakukan validasi instrumen, melakukan uji instrumen, observasi di kelas dan menganalisis penguasaan konsep siswa sebelum dilakukan perlakuan. Tahapan pelaksanaan yaitu melaksanakan pembelajaran sesuai dengan rancangan pembelajaran yang telah disusun. Kelas eksperimen menerapkan pembelajaran model inkuiri terbimbing dipadu edutainment, kelas kontrol positif dibelajarkan dengan inkuiri terbimbing dan kelas kontrol negatif dibelajarkan dengan konvensional. Setelah diberikan perlakuan, selanjutnya siswa diberi tes penguasaan konsep menggunakan soal tes untuk mengukur penguasaan konsep setelah diberikan perlakuan. Pada tahap pelaporan berisi tentang tahap analisis dan evaluasi hasil tes penguasaan konsep dinilai berdasarkan rubrik penskoran yang telah disusun. Data skor penguasaan konsep dianalisis dengan melakukan uji prasyarat berupa uji normalitas dan homogenitas serta uji hipotesis melalui bantuan program SPSS 25.0 for windows. 


\section{HASIL}

Uji Pengaruh Model Inkuiri Terbimbing Dipadu Edutainment terhadap Penguasaan Konsep

Data hasil penelitian ini disajikan dengan menghitung rerata skor awal, skor akhir, selisih dan rerata terkoreksi penguasaan konsep dari kelas yang dibelajarkan model inkuiri terbimbing dipadu edutainment, inkuiri terbimbing dan konvensional. Hasil perhitungan penguasaan konsep siswa dapat dilihat pada tabel 1.

Tabel 1. Rerata Nilai Penguasaan Konsep

\begin{tabular}{lccll}
\hline \multirow{2}{*}{ Kelas } & \multicolumn{2}{c}{ Rerata Skor } & \multirow{2}{*}{ Selisih } & \multirow{2}{*}{ Rerata Terkoreksi } \\
\cline { 2 - 4 } & Awal & Akhir & & \\
\hline InTer+edutainment & 37,031 & 76,510 & 39,479 & 76,526 \\
Inkuiri Terbimbing & 33,778 & 54,667 & 20,889 & 55,008 \\
Konvensional & 40,777 & 44,222 & 3,445 & 43,863 \\
\hline
\end{tabular}

Tabel 1 menunjukkan rerata nilai penguasaan konsep dari kelas yang dibelajarkan model inkuiri terbimbing dipadu edutainment, inkuiri terbimbing dan konvensional. Dari tabel tersebut dapat dilihat bahwa rerata nilai penguasaan konsep kelas yang dibelajarkan menggunakan model inkuiri terbimbing dipadu edutainment memiliki skor rerata terkoreksi paling tinggi. Sebagai syarat melakukan uji hipotesis, data harus terlebih dahulu diuji normalitas dan uji homogenitas. Hasil uji normalitas dan uji homogenitas menunjukkan bahwa data tersebut telah terdistribusi normal dan homogen. Hasil uji selengkapnya tentang data tersebut dapat dilihat pada tabel 2 dan 3.

Tabel 2. Hasil Uji Normalitas

\begin{tabular}{lllll}
\hline \multicolumn{1}{c}{ Kelas } & p Awal & Keterangan & p Akhir & Keterangan \\
\hline InTer+edutainment & 0,200 & Normalitas & 0,200 & Normalitas \\
Inkuiri Terbimbing & 0,200 & Normalitas & 0,200 & Normalitas \\
Konvensional & 0,200 & Normalitas & 0,184 & Normalitas \\
\hline
\end{tabular}

Tabel 3. Hasil Uji Homogenitas

\begin{tabular}{cclccl}
\hline Skor & F & df1 & df2 & Sig & Keterangan \\
\hline Skor awal penguasaan konsep & 1,841 & 2 & 89 & 0,165 & Homogen \\
Skor akhir penguasaan konsep & 2,794 & 2 & 89 & 0,067 & Homogen \\
\hline
\end{tabular}

Selanjutnya dilakukan uji hipotesis untuk data penguasaan konsep. Adapun hasil uji hipotesis yakni menggunakan uji anakova 1 jalur dengan bantuan program SPSS 25.0 for windows dengan taraf signifikansi 0,05. Adapun hasil uji hipotesis yang diperoleh dapat dilihat pada tabel 4.

Hasil uji beda data penguasaan konsep menggunakan uji Anacova menunjukkan nilai $\mathrm{F}_{\text {hitung }}$ sebesar 216,430 dengan $p$ value $=0,000<\alpha(0,05)$. Dengan demikian, $\mathrm{H}_{0}$ yang berbunyi tidak ada perbedaan penguasaan konsep antara siswa yang menerima model pembelajaran yang berbeda ditolak. Maka, ada perbedaan penguasaan konsep antara siswa yang menerima model pembelajaran diterima. Jadi, simpulannya adalah model inkuiri terbimbing dipadu edutainment berpotensi meningkatkan penguasaan konsep siswa.

Tabel 4. Hasil Uji Hipotesis Penguasaan Konsep

\begin{tabular}{lrrrrr}
\hline Source & Type III Sum of Squares & Df & Mean Square & \multicolumn{1}{c}{ F } & Sig. \\
\hline Corrected Model & $16958,412^{\mathrm{a}}$ & 3 & 5652,804 & 145,971 &, 000 \\
Intercept & 7131,448 & 1 & 7131,448 & 184,154 &, 000 \\
Peng. Konsep & 33,862 & 1 & 33,862 &, 874 &, 352 \\
Model & 16762,745 & 2 & 8381,372 & 216,430 &, 000 \\
Error & 3407,848 & 88 & 38,726 & & \\
Total & 339086,489 & 92 & & & \\
\hline Corrected Total & 20366,260 & 91 & & & \\
\hline
\end{tabular}

Adapun hasil peningkatan penguasaan konsep siswa pada kelas yang dibelajarkan dengan konvensional, inkuiri terbimbing, inkuiri terbimbing dipadu edutainment dapat dilihat pada gambar 1. 


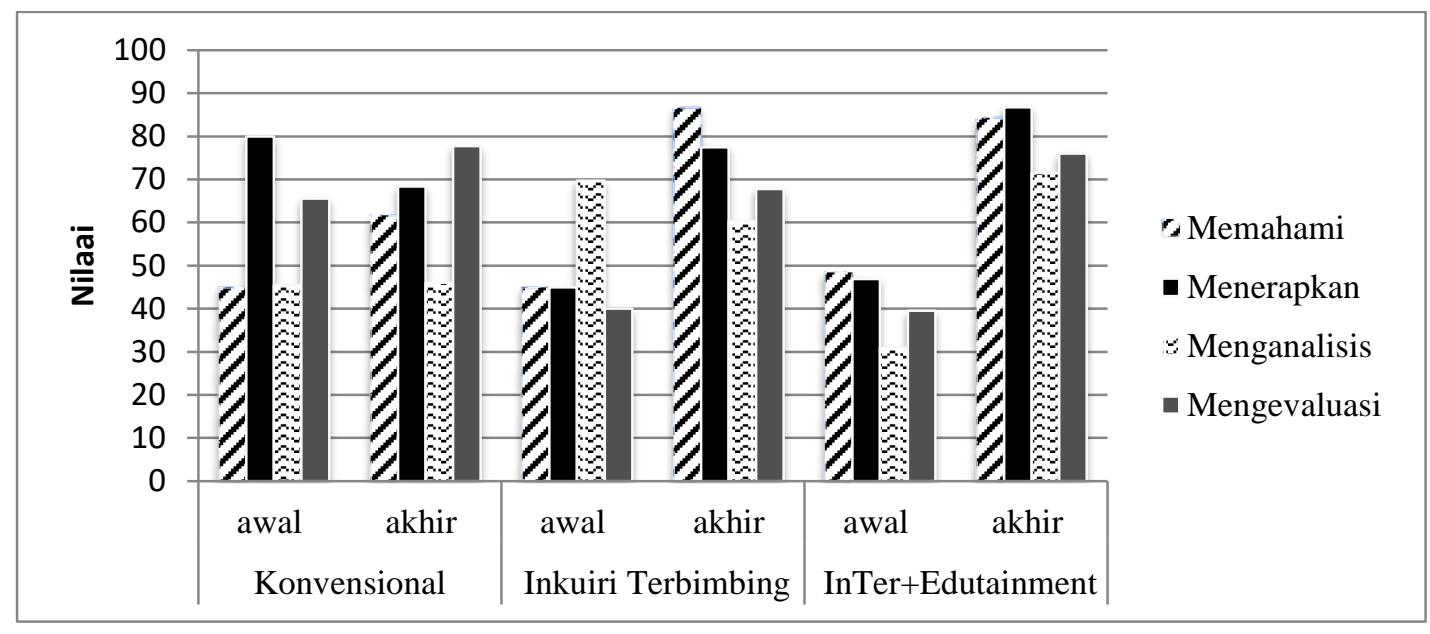

Gambar 1. Diagram Peningkatan Indikator Penguasaan Konsep

\section{PEMBAHASAN}

Hasil uji beda penguasaan konsep yang dibelajarkan dengan model inkuiri terbimbing dipadu edutainment berbeda nyata dengan model inkuiri terbimbing dan konvensional. Adapun peningkatan indikator penguasaan konsep yang dilakukan oleh peneliti untuk mengukur pencapaian penguasaan konsep siswa pada beberapa materi yang dibelajarkan. Kelas yang dibelajarkan dengan model inkuiri terbimbing dipadu edutainment memiliki peningkatan penguasaan konsep yang lebih tinggi dibandingkan kelas inkuiri terbimbing dan konvensional. Hal tersebut ditunjukkan pada masing-masing indikator soal penguasaan konsep yang ada yakni indikator memahami (C2), menerapkan (C3), menganalisis (C4), dan mengevaluasi (C5). Pada kelas yang dibelajarkan secara konvensional nilai penguasaan konsep pada indikator memahami dan mengevaluasi terjadi peningkatan akan tetapi tidak pada indikator menerapkan dan menganalisis. Siswa dengan pembelajaran model inkuiri terbimbing mengalami peningkatan, kecuali pada indikator menganalisis. Siswa yang dibelajarkan model inkuiri terbimbing dipadu edutainment pada masing-masing indikator penguasaan konsep meningkat secara signifikan. Dengan demikian, nilai rerata awal dan akhir penguasaan konsep yang dibelajarkan model inkuiri terbimbing dipadu edutainment secara signifikan setiap indikator meningkat dan berbeda dengan kelas yang dibelajarkan inkuiri terbimbing dan konvensional.

Kegiatan pembelajaran yang dilaksanakan dengan model inkuiri terbimbing dipadu edutainment memberikan kesempatan siswa untuk melakukan kegiatan mengonstruksi dan menemukan jawaban sendiri sehingga siswa lebih tertantang dalam penemuannya. Selain itu, unsur edutainment juga memberikan respon yang positif dalam hal suasana belajar dan menjadi pemanis dalam kegiatan belajar. Pemanfaatan permainan mendidik dan keterampilan karya yang termasuk dalam unsur edutainment menjadikan siswa lebih nyaman untuk belajar. Beberapa pertanyaan untuk mengetahui seberapa paham terhadap materi yang disampaikan oleh guru dikemas dalam bentuk permainan seperti talking stick, puzzle, bermain peran dan kotak kartu misterius, sedangkan unsur keterampilan berkarya untuk meningkatkan penguasaan konsep siswa peneliti menggunakan mind map, peta konsep dan poster. Dari kedua unsur edutainment dapat menjadi pelengkap dalam kegiatan pembelajaran inkuiri terbimbing. Meskipun keterampilan berkarya dan permainan mendidik hanya dijadikan pelengkap atau pemanis namun berdampak positif terhadap nilai penguasaan konsep siswa.

Keuntungan dan tantangan pada pembelajaran inkuiri dibandingkan pembelajaran konvensional adalah pembelajaran inkuiri mengaitkan fenomena yang dekat dengan siswanya, sedangkan pembelajaran konvensional adalah pembelajaran yang menciptakan pembelajaran yang pasif dan membosankan bagi siswa. Guru mendorong dan membimbing siswa untuk mengembangkan pertanyaan, mencari informasi, menganalisis data dan mengomunikasikan hasil temuannya. Hal tersebut membantu siswa untuk mengonstruk pengetahuan baru dan berpartisipasi secara aktif dalam kelas. Pembelajaran berbasis inkuiri lebih sukses mengembangkan integrasi pengetahuan pada siswa (Cove, 2004). Sementara penggunaan model konvensional proses pembelajarannya menekankan penyampaian materi secara verbal dari guru kepada siswa dengan maksud siswa dapat menguasai materi pembelajaran secara optimal (Yeritia, Wahyudi, \& Rahayu, 2018).

Hasil penelitian Yeritia, Wahyudi, \& Rahayu (2018) siswa senang dengan pembelajaran inkuiri karena mendapatkan pengalaman secara langsung dalam proses pembelajaran. Inkuiri terbimbing lebih menekankan pada aktivitas secara maksimal melalui kegiatan eksperimen untuk mencari dan menemukan konsep sendiri sehingga siswa lebih mudah memahami konsep yang rumit dan abstrak disertai pengalaman yang nyata dan terhindar dari cara belajar menghafal. Leonor (2015) model inkuiri terbimbing mampu meningkatkan penguasaan konsep siswa sehingga dipercaya dapat menunjukkan hasil penguasaan konsep yang lebih baik (Sholikhan, 2017). Pernyataan yang sama disebutkan bahwa model inkuiri terbimbing merupakan salah satu cara untuk mengembangkan pengetahuan dengan mengonstruksi konsep-konsep (Sarwi, Wasisakti, Sutardi., 2015). Penerapan pembelajaran model inkuiri terbimbing dapat memberikan respons positif terhadap kegiatan pembelajaran yang dilakukan serta 
dapat meningkatkan pemahaman siswa dalam belajar (Spiess, 2004). Pembelajaran inkuiri juga dapat membantu siswa dalam membangun pengetahuan melalui proses berpikir dan bertanya serta adanya kombinasi permainan dapat meningkatkan hasil belajar kognitif siswa (Sukma, Komariyah, \& Syam, 2015).

Pembelajaran dengan permainan mendidik dapat membuat siswa lebih menumbuhkan pemahaman konsep. Proses pembelajaran menerapkan edutainment berupa permainan mendidik memiliki kelebihan yaitu menarik dan membuat siswa tidak bosan dalam proses pembelajaran karena permainan mendidik dan tantangan yang diberikan guru menjadikan siswa lebih menguasai konsep yang diajarkan (Umar, Parmin \& Wusqo., 2016). Entertainment memberikan suasana belajar yang tidak jenuh dan tidak tegang dalam proses pembelajaran karena belajar sekaligus mendapatkan sensasi dari sebuah hiburan yang diterapkan dalam bentuk sebuah permainan mendidik (Rusydi., 2017). Agar siswa merasa senang dan terlibat aktif dalam proses pembelajaran edutainment merupakan pelengkap untuk dapat meningkatkan kualitas siswa dalam belajar karena pembelajaran edutainment berdampak pada peningkatan hasil belajar kognitif siswa (Zakaria, Sumardi \& Berman, 2017).

Berdasarkan pernyataan di atas dapat maka keberadaan model inkuiri terbimbing dipadu edutainment dalam proses pembelajaran dapat dijadikan solusi dalam meningkatkan penguasaan konsep siswa karena mampu memberikan kenyamanan siswa dalam belajar sehingga berdampak pada peningkatan penguasaan konsep siswa. Meskipun edutainment hanya dijadikan sebuah pemanis dalam pembelajaran namun memberikan pengaruh positif terhadap pencapaian pembelajaran. Terbukti bahwa beberapa permainan mendidik dan keterampilan berkarya yang dapat membantu siswa untuk menguatkan konsep setelah melakukan eksperimen atau observasi.

Adapun kekurangan penelitian ini yaitu hasil penguasaan konsep pada kelas model inkuiri terbimbing dipadu edutainment belum sepenuhnya berhasil walaupun dibandingkan kelas yang dibelajarkan model inkuiri terbimbing dan kelas konvensional hasil penguasaan konsep paling tinggi. Soal yang digunakan hanya berupa pilihan ganda yang memungkinkan jawaban opsional keberuntungan, penggunaan permainan mendidik sebagai penguatan juga belum dapat diterapkan sepenuhnya karena keterbatasan waktu dan mengejar materi sehingga ada bermain peran yang tidak dapat diterapkan. Dengan demikian, perlu siasat penggunaan waktu yang optimal untuk menerapkan pembelajaran model inkuiri terbimbing dipadu edutainment.

\section{SIMPULAN}

Berdasarkan hasil penelitian, simpulan yang dapat diperoleh yaitu model inkuiri terbimbing dipadu edutainment berpotensi dalam meningkatkan penguasaan konsep siswa. Saran yang dapat diajukan berdasarkan hasil dan pembahasan pada penelitian ini untuk melaksanakan pembelajaran adalah sebagai berikut. Pertama, pembelajaran model inkuiri terbimbing dipadu edutainment sebagai salah satu alternatif dalam meningkatkan penguasaan konsep namun guru atau peneliti harus dapat mengatur waktu dengan baik karena pelaksanaan edutainment membutuhkan waktu yang cukup lama. Kedua, instrumen pengukuran penguasaan konsep dapat menggunakan esai untuk hasilnya lebih baik, permainan mendidik perlu menggunakan media digital untuk mengetahui hasil penguasaan konsep siswa serta keterampilan berkarya yang diterapkan fokus untuk pengayaan dan evaluasi siswa dalam penguasaan konsep.

\section{DAFTAR RUJUKAN}

Adieze, C. (2016). Effects of Edutainment, Scaffolding Instructional Models and Demonstration Method on Students' Academic Performance in Business Studies in Secondary Schools in Abia South Senatorial Zone in Abia State, Nigeria, 2(1), 72-84

Ali, L. U. (2018). Pengelolaan Pembelajaran IPA Ditinjau dari Hakikat Sains pada SMP di Kabupaten Lombok Timur. Prisma Sains: Jurnal Pengkajian Ilmu dan Pembelajaran Matematika dan IPA IKIP Mataram, 6(2), 103-112.

Annisa, D., \& Rohaeti, E. (2018). The Effect of Inquiry-Based Learning on Students 'Understanding of the Chemical Equilibrium Concept. Conference Paper in AIP Conference Proceedings, 080004(October). https://doi.org/10.1063/1.5062823

Cai, Y., Lu, B., Fan, Z., Indhumathi, C., Lim, K. T., Chan, C. W., ... Li, L. (2006). Bio-edutainment: Learning Life Science Through X Gaming. Computers and Graphics (Pergamon), 30(1), 3-9. https://doi.org/10.1016/j.cag.2005.10.003

Chopra, V., \& Chabra, S. (2013). Digantar in India: A Case Study for Joyful Learning. Journal of Unschooling and Alternative Learning, 7(13), 28-44.

Chowdhury, R. (2004). Inquiry Based Learning as an Instructional Strategy to Increase Student Achievement in Math and Science. Doctoral Student of Instructional Design and Technology The University of Memphis, 177-188.

Darwis, R. (2015). Pembelajaran Berbasis Inkuiri dengan Aktivitas Laboratorium untuk Meningkatkan Penguasaan Konsep Siswa SMP. Prosiding Simposium Nasional Inovasi dan Pembelajaran Sains 2015, 493-496.

Eastwell, P. (2006). Levels of Enquiry. The Science Education Review, 5(2), 61-63.

Fatwa, M. W., Harjono, A., \& Jamaluddin. (2018). Pengaruh Model Pembelajaran Inkuiri Terbimbing terhadap Keterampilan Proses dan Penguasaan Konsep Sains Ditinjau dari Pengetahuan Awal Peserta Didik. Jurnal Pendidikan Fisika dan Teknologi, 4(1).

Febriyani, S., Isnaeni, W., \& Irsadi, A. (2016). Pengaruh Penerapan Strategi Bioedutainment Model Teams Games Tournament pada Pembelajaran Materi Alat Indera Manusia terhadap Keaktifan dan Hasil Belajar Siswa. Journal of Biology 
Education, 5(3), 168-173.

Hariyadi, D., Ibrohim., \& Rahayu, S. (2016). Pengaruh Model Pembelajaran Inkuiri Terbimbing Berbasis Lingkungan Terhadap Keterampilan Proses dan Penguasaan Konsep IPA Siswa Kelas VII pada Materi Ekosistem. Jurnal Pendidikan: Teori, Penelitian, dan Pengembangan, 1(8),1567-1574.

Hutahaean, R., \& Harahap, M. B. (2017). The Effect of Scientific Inquiry Learning Model Using Macromedia Flash on Student's Concept Understanding and Science Process Skills in Senior High School. IOSR Journal of Research \& Method in Education, 7(4), 29-37. https://doi.org/10.9790/7388-0704012937

Leonor, J. P. (2015). Exploration of Conceptual Understanding and Science Process Skills : A Basis for Differentiated Science Inquiry Curriculum Model. International Journal of Information and Education Technology, 5(4), $255-259$. https://doi.org/10.7763/IJIET.2015.V5.512

Marianti, A. (2006). Bioedutainment Strategi dalam Pembelajaran Biologi. Makalah. Dipresentasikan pada Pelatihan Eduwisata Biologi Guru SMP se kota Semarang, di Jurusan Biologi FMIPA Unnes di Semarang tanggal 25-26 November 2006.

Mulyani, S., A. Marianti., N.E. Kartijono., T. Widianti., S. Saptono., K.K. Pukan., \& S. H. Bintari. (2008). Jelajah Alam Sekitar (JAS) Pendekatan Pembelajaran Biologi. Semarang: Jurusan Biologi FMIPA Universitas Negeri Semarang.

Nisa, E. K., Koestiari, T., Habibbulloh, M., \& Jatmiko, B. (2018). Effectiveness of Guided Inquiry Learning Model to Improve Students' Critical Thinking Skills at Senior High School. Journal of Physics: Conference Series, Volume 997, conference 1

Ogan-bekiro, F., \& Arslan, A. (2014). Examination of the Effects of Model-Based Inquiry on Students' Outcomes: Scientific Process Skills and Conceptual Knowledge. Procedia - Social and Behavioral Sciences 141, 1187-1191. https://doi.org/10.1016/j.sbspro.2014.05.202

Pan, Z. (2006). Special Issue on Edutainment (E-learning and game). Computers and Graphics (Pergamon), 30(1), 1-2. https://doi.org/10.1016/j.cag.2005.10.002

Pasawano, T. (2015). Results of Enhanced Learning with the Edutainment Format. Procedia - Social and Behavioral Sciences, 176, 946-951. https://doi.org/10.1016/j.sbspro.2015.01.563

Pramesthi, H. N., S, A. N. C., \& Vh, S. (2015). Penerapan Pendekatan Joyful Learning dengan Metode Guided Discovery untuk Meningkatkan Materi Hidrokarbon Siswa Kelas X SMA Negeri 1 Ngemplak Boyolali Tahun Ajaran 2013/2014. Jurnal Pendidikan Kimia, 4(1), 204-210.

Praptiwi, L., Sarwi., \& Handayani, L. (2012). Efektivitas Model Pembelajaran Eksperimen Inkuiri Terbimbing Berbantuan My Own Dictionary untuk Meningkatkan Penguasaan Konsep dan Unjuk Kerja. Unnes Science Education Journal, 1(2), 8695.

Sarwi., Wasisakti, D. P., \& Sutardi (2015). Utilization of the Guided Inquiry Learning Model to Develop Students’ Conservation Character, 2015(ICMSE).

Rusydi, N. A. (2017). The Influence of The Implementation of Edutainment Method in Learning on Social Science Learning Results at S Kartika XX-I In Mamajang Sub-District of Makassar City. Tesis tidak diterbitkan. Universitas Negeri Makassar, Makassar.

Shih, J \& Su, H. Y. (2014). Analyzing Children's Cognitive Activities in Digital Problem-solving Learning Games. Learning, 651-658.

Sholikhan. (2017). Understanding Concepts Through Inquiry Learning Strategy, 7(1), 97-102. https://doi.org/10.9790/738807010597102

Sofyan, M. A., Wasis., \& Ibrahim, M. (2017). Pengembangan Perangkat Pembelajaran Berdasarkan Masalah Berbasis Edutainment untuk Melatihkan Kreativitas Siswa SMK Jurusan Otomotif pada Materi Fluida Statis. Jurnal Penelitian Pendidikan Sains, 7(1), 1431-1440.

Sorathia, K., \& Servidio, R. (2012). Learning and Experience: Teaching Tangible Interaction \& Edutainment. Procedia - Social and Behavioral Sciences, 64, 265-274. https://doi.org/10.1016/j.sbspro.2012.11.031

Sukma., Komariyah., L., \& Syam M. (2015). Pengaruh Model Pembelajaran Inkuiri Terbimbing (Guided Inquiry) dan Motivasi terhadap Hasil Belajar Fisika Siswa. Saintifika, 18(1), 59-63.

Umar., N. H. M., Parmin., \& Wusqo, I. U. (2016). Pengaruh Media Kartu Pintar Tumbuhan Berbasis Science Edutainment terhadap Minat Belajar dan Pemahaman Konsep Siswa Tema Gerak Tumbuhan. Unnes Science Education Journal, 5(2), $1288-1297$.

Ural, E. (2016). The Effect of Guided-Inquiry Laboratory Experiments on Science Education Students' Chemistry Laboratory Attitudes, Anxiety, and Achievement, 4(4), 217-227. https://doi.org/10.11114/jets.v4i4.1395

Yeritia, S., Wahyudi., \& Rahayu, S. (2018). Pengaruh Moedel Inkuiri Terbimbing terhadap Penguasaan Konsep dan Kemampuan Berpikir Kritis Fisika Peserta Didik Kelas X SMA N 1 Kuripan Tahun Ajaran 2017/2018. Jurnal Pendidikan Fisika dan Teknologi, 3(2), 181-187. DOI: http://dx.doi.org/10.29303/jpft.v3i2.398

Zakaria, A., Sumardi, K., \& Berman, E. T. (2017). Penerapan Metode Pembelajaran Edutainment pada Pembelajaran Psychometric untuk Meningkatkan Hasil Belajar Siswa SMK. Journal of Mechanical Engineering Education, 4(1), 28-33.

Zeidan, A. H., \& Jayosi, M. R. (2015). Science Process Skills and Attitudes toward Science among Palestinian Secondary School Students, 5(1), 13-24. https://doi.org/10.5430/wje.v5n1p13 
Febriyani, Suwono, Ibrohim, Potensi Model Inkuiri Terbimbing... 1624 